P LA N T B REE D ING AND SEED SCIENCE

DE GRUYter DOI: $10.2478 / \mathrm{v} 10129-011-0062-6$

G

Elham Nikmanesh, Mohammadhadi Pahlevani, Seyed Esmaeil Razavi

Department of Plant Breeding and Biotechnology, College of Agriculture, Gorgan University of Agricultural Sciences and Natural Resources,

P.O. Box 386, Gorgan, Iran

\title{
SELECTION-BASED HERITABILITY OF RESISTANCE TO PYTHIUM ULTIMUM IN SAFFLOWER
}

\begin{abstract}
Damping-off disease caused by Pythium ultimum can kill both germinating seeds and young seedlings and cause considerable damage in safflower cultivation. An estimation of heritability lets safflower breeders determine the most effective method for improving seedling emergence in soils infected with $P$. ultimum, the causal agent of seed rot and damping-off. Two cycles of selection were performed to estimate the realized heritability of resistance to the pathogen in five safflower populations. Undamaged seedlings were selected as resistant individuals and were kept to produce seed. The results showed that selection for two consecutive generations increased the emergence of seedlings in Pythium-infected soil from 46 to $53 \%$. The heritability estimates varied between 1.72 and $77.66 \%$ over the genotypes and environments, in inverse proportion to the severity of the disease. Estimates of heritabilities showed that genes conferring resistance to P. ultimum in safflower are highly heritable and would respond to selection breeding, particularly in some of the studied genotypes, like Isfahan and Zarghan259. However, different breeding methods must be explored for other genotypes.
\end{abstract}

Key words: additive, emergence, genotype, seed, zoospore.

\section{ABBREVIATIONS}

- $\quad$ Env. 1: Environment 1

- $\quad$ Env. 2: Environment 1

- SI: Susceptibility Index

Communicated by Edward Arseniuk 


\section{INTRODUCTION}

Safflower (Carthamus tinctorius L.), a member of the family Compositae, is an important agronomic and medicinal plant. It is a branching, thistle-like herbaceous annual plant, with numerous spines on leaves and bracts, grown mainly as an oilseed. Oil content of the achenes is frequently $30-45 \%$, and protein content can be as high as $24 \%$. The flowers are used as dye sources and for medicinal or ornamental purposes. The deep taproot and xerophytic attribute of its spines give safflower good drought and heat tolerance. The crop may use considerable amounts of soil moisture, but it can not tolerate standing water around the crown for even a few hours in warm weather. Such wet conditions intensify the spread of soil-borne pathogens such as Pythium and Phytophthora (Mündel et al. 1995; Rubis, 1981). These pathogens parasitize seeds and invade the hypocotyle or tissues of first internodes and cause rotting and collapse and finally decay in safflower seedlings (Kolte, 1985; Thomas, 1970). Pythium ultimum Trow is one of the most important causal agents of damping-off, seed rot, and death of underground parts in safflower and many other plants (Huang et al., 1992; Mundel et al., 1997). P. ultimum is widespread in all arable lands in the world and has been reported in many countries like Australia, Argentina, India, Mexico, Afghanistan, and Iran (Sharifnabi and Saiedi, 2004). The first observation of seedling death or damping-off in safflower was reported by Classen from Nebraska in 1949 (Cormack and Harper, 1952). Pythium damping-off has also been reported in wheat, canola, common pea, sugar beet and common bean (Higginbotham et al., 2004; Bardin et al., 2004; Ahmadzadeh et al., 2004). Breeding and cultivation of resistant cultivars is considered the most efficient, cost effective and environmentally acceptable means of controlling the disease. Increasing the frequency of favorable gene(s) by selection and keeping resistant individuals in the population is a simple and old way of improving plant resistance against fungus pathogens. Success in improving resistance via selection depends on the amount of heritability, so selection will be effective just for traits governed by additive genetic effects.

Although evidence of resistance to Pythium has been found in other crops (Rosso et al., 2008; Yang et al., 2005), no reports are available that identify safflower cultivars with complete and durable resistance to Pythium spp. Therefore, knowledge of the heritability of resistance is essential for the efficient development of resistant cultivars. Information regarding genetic control of resistance to $P$. ultimum in safflower is rare, although some reports on similar pathogens like Phytophthora, Alternaria and Macrophomina have been published for safflower and other crop plants (Kozik et al., 1991; Mundel et al., 1997; Pahlavani et al., 2007). In cotton, selection for two consecutive generations created a significant difference between 
parent and offspring in resistance to Pythium as some offspring showed more resistance than their parents (Johnson and Palmer, 1985). Resistance to $P$. aphanidermatum in the medicinal plant periwinkle (Catharanthus roseus) appeared to be governed by a single gene with a broad-sense heritability range of 79 to $85 \%$ (Kulkarni and Baskaran, 2003).

Since most of the safflower fields in Iran are naturally infested by $P y$ thium, this study was conducted:

(1) to estimate heritability of resistance to P. ultimum in five different safflower populations, and

(2) to evaluate the effects of selection on the improvement of seed emergence and seedling survival in soil infected by the pathogen.

\section{MATERIALS AND METHOD}

This research was performed at the plant breeding laboratory and research farm of Gorgan University of Agricultural Sciences and Natural Resources, Gorgan, Iran, during 2009 to 2011. Five safflower populations, genotypes Zarghan259, Isfahan, Syrian, Hartman and 34040, were employed in this study. The study followed two steps for each population; first, building an after-selection population by gathering seeds from Pythium-resistant plants in each genotype; second, comparing the before-selection population (parental population) for each genotype, to the after-selection population for level of resistance to the pathogen. Selection was performed for two successive generations.

During the two first years (2009 and 2010), seeds of resistant individuals were obtained by planting each population in soil infected with P. ultimum. A zoospore suspension of the pathogen was applied to infect the soil. Cornmeal-agar (CMA) medium was used for fungus culture, after which square fragments of the culture were dropped into the autoclaved water and then kept for four days under fluorescent light to produce zoospores. Then the number of zoospores was counted by a hemocytometer, and the suspension was prepared with a final concentration of $10^{5}$ zoospores in one milliliter. The seeds, after having been disinfected with five \% bleach (Sodium hypochlorite) for five minutes, were rinsed with distilled water until clear, and then immersed in the suspension of $P$. ultimum for 20 minutes to make sure that the seeds were inoculated with the pathogen. Five hundred inoculated seeds of each genotype were arranged on a paper towel soaked with the pathogen suspension (Kozik et al., 1991; Govindappa et al., 2005). Another paper towel of the same size was put over each towel to cover the seeds. The paper towels containing seeds were rolled and put in a plastic bag to prevent loss of water. All towels containing seeds were then placed in a $22 \pm 2$ degree centigrade dark incubator for one night before planting in soil. The inoculated seeds were planted in soil that was also infected with 
the suspension. The soil was sterilized before infection in an autoclave at $121^{\circ} \mathrm{C}$ pressure $1.5 \mathrm{~kg} / \mathrm{cm}^{2} \mathrm{~s}$. Seeds of before- and after-selection were planted twice in early March 2011 and early May 2011 (Env. 1 and Env. 2, respectively) in pathogen-infected and also pathogen-free soil to quantify the amount of improvement in resistance gained by selection. Each experimental unit consisted of 100 inoculated seeds and the experiment was performed in eight replications for both infected and sterilized soil. Counting the number of emerged seeds began at appearance of first seedlings and continued until the number of emerged seeds was fixed. Susceptibility in$\operatorname{dex}(S I)$ as follows was calculated to figure out the severity of infection in Env.1 and Env. 2:

$$
S I=1-\left(\frac{\bar{Y}_{i}}{\bar{Y}_{f}}\right)
$$

$\bar{Y}_{Y}$ where $\bar{Y}_{i}$ - average number of emerged seedlings in pathogen-free plots; $\overline{Y_{f}}$ - average number of emerged seedlings in pathogen-infected plots. The higher amounts of SIs show that the pathogen caused more disease severity on the host.

Realized heritability calculated according to the equation of Fehr (1987) with some modifications:

$$
h^{2}=\frac{\left(\bar{Y}_{a i}-\bar{Y}_{b i}\right)}{\left(\bar{Y}_{b f}-\bar{Y}_{b i}\right)} \times 100
$$

where, $\bar{Y}_{a t}$ - average number of emerged seedlings for after-selection population of a genotype in pathogen-infected plots; $\bar{Y}_{b l}-$ Average number of emerged seedlings for before-selection population of a genotype in pathogeninfected plots; $\bar{Y}_{b f}$ - Average number of emerged seedlings for beforeselection population of a genotype in pathogen-free plots.

\section{RESULTS AND DISCUSSION}

Rotting seeds, invasion of the hypocotyls of young seedlings, and damping-off were the most visible symptoms in pathogen-infected plots (Fig. 1). The pathogen, P. ultimum, induced more disease in Env. 1 than in Env. 2, so that SI was 0.14 and 0.35 for these two conditions, respectively (Table 1). By definition, whenever the susceptibility index (SI) is more, the disease severity in infected soil will be more. Therefore, environmental conditions were more favorable for P. ultimum activity in Env. 2 than in 
Env. 1 (Table 1). SI of 0.14 and 0.35 also indicates that surviving individuals in pathogen-infected plots were 14 and 35 percent fewer than in pathogen-free plots, respectively. The different percentages of survived seedlings implied that intensity of selection was not similar in Env.1 and Env.2. This difference in pathogenesis could imply that lower temperature and higher humidity took place in early March for Env. 1 than in early May for Env. 2. So the effect of fungus varied over the two environments.

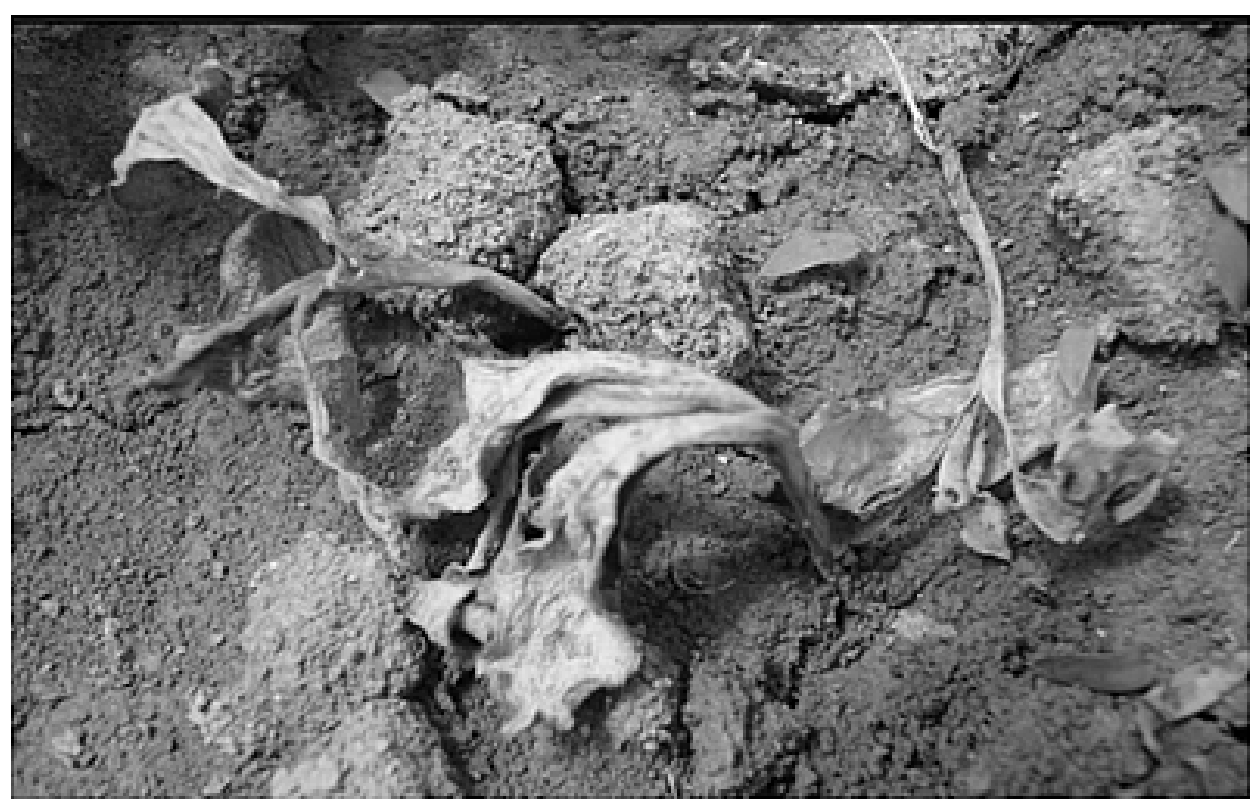

Fig. 1. Symptoms of damping-off observed on safflower seedlings growing in soil inoculated with P. ultimum

Table 1

Susceptibility index (SI) of safflower populations to $P$. ultimum

\begin{tabular}{cccc}
\hline Environment & $\begin{array}{c}\text { Percent of seedling } \\
\text { emergence pathogen-free } \\
\text { soils }\left(\bar{Y}_{f}\right)\end{array}$ & $\begin{array}{c}\text { Percent of seedling } \\
\text { emergence pathogen- } \\
\text { infected soil }\left(\bar{Y}_{i}\right)\end{array}$ & $\begin{array}{c}\text { Susceptibility } \\
\text { index }(\mathrm{SI})\end{array}$ \\
\hline Env. $1 \dagger$ & 57.96 & 49.70 & 0.14 \\
Env. 2 & 57.96 & 37.64 & 0.35 \\
\hline
\end{tabular}

$\dagger$ Env. 1: Seeds were planted in early March, 2011.; Env. 2: Seeds were planted in early May, 2011.

The results showed that selection improved percent of emergence in $P y$ thium-infected soil in all studied genotypes (Table 2). Although selection was effective for all studied genotypes, it had more effect when seeds were planted in infected soil in early March 2011 (Env.1). In an average of all genotypes, selection for two consecutive generations increased the emergence of seedlings from 46.34 to 53.07 in Env.1 ( $\mathrm{SI}=0.14)$ and from 35.90 
to 39.38 in Env. 2 ( $\mathrm{SI}=0.35$ ) (Table 2). In Env. 1, the highest improvement due to selection was observed in the population of genotype Zarghan259, and the lowest in genotypes Hartman and Syrian (Table 2). In Env. 2, the most improvement was observed in the population of Syrian and the lowest in Hartman (Table 2).

Mean seedling emergence of before- and after-selection populations of safflower in P. ultimum -free and -infected soil

† Env. 1: Seeds were planted in early March, 2011.; Env. 2: Seeds were planted in early May, 2011.

\begin{tabular}{|c|c|c|c|c|c|c|c|c|}
\hline \multirow{2}{*}{ Genotype } & \multicolumn{2}{|c|}{ Sterile soil } & \multicolumn{2}{|c|}{$\begin{array}{l}\text { Infected soil in Env. } \\
\qquad 1 \dagger(\mathrm{SI}=0.14)\end{array}$} & \multicolumn{2}{|c|}{$\begin{array}{l}\text { Infected soil in Env. } 2 \\
\qquad(\mathrm{SI}=0.35)\end{array}$} & \multicolumn{2}{|c|}{ Heritability (\%) } \\
\hline & $\begin{array}{l}\text { Before - } \\
\text { selection }\end{array}$ & $\begin{array}{c}\text { After - } \\
\text { selection }\end{array}$ & $\begin{array}{l}\text { Before - } \\
\text { selection }\end{array}$ & $\begin{array}{l}\text { After - } \\
\text { selection }\end{array}$ & $\begin{array}{l}\text { Before - } \\
\text { selection }\end{array}$ & $\begin{array}{c}\text { After - } \\
\text { selection }\end{array}$ & Env. 1 & Env. 2 \\
\hline Syrian & 64.75 & 58.00 & 52.66 & 53.75 & 37.00 & 46.00 & 8.96 & 32.43 \\
\hline Hartman & 69.25 & 52.25 & 54.33 & 55.50 & 40.25 & 40.75 & 7.82 & 1.72 \\
\hline Isfahan & 40.75 & 42.66 & 33.25 & 39.00 & 28.00 & 31.25 & 76.66 & 26.35 \\
\hline Zarghan259 & 60.75 & 62.25 & 29.25 & 40.75 & 29.75 & 30.67 & 71.50 & 5.88 \\
\hline 34040 & 80.25 & 48.75 & 62.75 & 76.33 & 44.50 & 48.25 & 77.61 & 10.48 \\
\hline Mean & 63.15 & 52.78 & 46.34 & 53.07 & 35.90 & 39.38 & 48.51 & 15.37 \\
\hline
\end{tabular}

Variable heritabilities were estimated for seedling emergence in Pythiuminfected soil. The estimates varied between 7.82 and $76.66 \%$ in Env. 1; and between 1.72 and $32.43 \%$ in Env. 2 (Table 2). On average, heritability of emergence in infected soil for Env. 1 and Env.2 was estimated at 48.51 and 15.37 respectively. In Env. 1 (SI=0.14), the highest estimation of heritability for emergence in Pythium-infected soil belonged to genotypes Isfahan, 34040 and Zarghan259 (76.66, 77.61 and $71.50 \%$, respectively; Table 2). Estimation of heritability for Syrian and Hartman in Env.1 was 8.96 and $7.82 \%$ respectively (Table 2$)$. In Env. $2(\mathrm{SI}=0.35$ ), the greatest heritability of seedling emergence in Pythium-infected soil was obtained for Syrian and Isfahan (32.43 and 26.35 respectively), and it was very low for other genotypes (Table 2).

In this study, heritability of response to P. ultimum was estimated in two different levels of pathogenesis, moderate with $\mathrm{SI}=0.14$, and severe with $\mathrm{SI}=0.35$. In the moderate pathogenesis of $P$. ultimum, narrow-sense heritability estimates for resistance to Pythium damping-off ranged from 7.82 to $77.66 \%$ with a mean of $48.51 \%$, and in severe conditions, the heritability estimates were between 1.72 to $32.43 \%$ with a mean of $15.37 \%$. Theses 
estimates show that genes conferring resistance to $P$. ultimum in safflower are somewhat heritable and would respond to selection breeding which could be facilitated by modern biotechnological tools, such as markerassisted breeding techniques. The first utilization of heritability value for breeders is in deciding how effective selection might be, particularly for phenotypic selection. The efficiency of selection as a breeding method for improving safflower germination in fungi-infected soil has been examined before (Palooj, 2010). The proficiency of selection for increasing resistance to pathogens has also been indicated in other crops. In cotton, selection for two consecutive generations could create a significant difference between parent and offspring in resistance to Pythium as some offspring showed more resistance than their parents (Johnson and Palmer, 1985). Hollingsworth et al. (2005) investigated brown root rot of alfalfa, caused by Phoma sclerotioides and showed that after one cycle of selection, the plants exhibited a reduced level of disease severity compared with the plants of cycle zero. Results of an investigation on sesame demonstrated that heritability of resistance to root rot (Macrophomina phaseolina) was high enough to perform selection (El-Bramawy and Abdul Wahid, 2006). Since seedling emergence of the before- and after-selection in the populations was used here, the estimations indicate reliable heritability. Resistance to pathogens having a vast range of hosts, such as Pythium, is generally nonspecific and is expected to be durable (Bruehl, 1983). Although durability of nonspecific resistance is generally believed to be the result of its polygenic nature, mono/oligogenic-nonspecific resistance has also been found to be durable (Johnson 1983). Gharderi et al. (2011) indicated that more than one gene is involved in the control of disease susceptibility index of safflower genotypes in P. ultimum-infected soil.

As a noticeable finding in this study, estimates of heritability varied over five studied populations from low (1.72\% in Hartman in Env. 2) to high (77.66 \% in Isfahahn in Env. 1). A high heritability occurs when the offspring of the selected parents differ from the original population almost as much as the selected parents do, and a low heritability occurs when the offspring of the selected parents differ little from the original population, in spite of a big difference between the population as a whole and the selected parents. These differences could be explained by the unequal gene frequency and additive genetic variance of resistance which exists in each population (Falconer and MacKay, 1996). Thus, selection would be an effective way to breed resistance to $P$. ultimum in genotype Isfahan with enough heritability in both Env.1 and Env.2 (Table 2). Estimates of heritability were not enough to suggest selection as a superior breeding method for improving resistance to the pathogen in Hartman, so different breeding methods must be explored in this population. For other genotypes, there was not a good correspondence of heritabilities over two studied environ- 
ments. So, in severe disease conditions, selection would be efficient for Syrian and in moderate conditions would be helpful just for Zarghan259 and 34040 (Table 2). By definition, heritability is the proportion of total variation in the population that can be attributed to variation in genetic, not environmental, factors. Therefore, better control of environmental effects might be needed to obtain success with selection in these two genotypes. In field pea, it has been proven that resistance to Mycosphaerella pinodes can be improved through accurate control of environmental factors by progeny selection from crosses of the most resistant lines (Zhang and Gossen, 2007). Longer term recurrent selection is also likely to raise the emergence of these populations at Pythium-infected soil to a level required for commercial safflower cultivars.

\section{REFERENCES}

Ahmadzadeh M, Sharif-Tehrani A, Hejaroud G, Zad J., Okhovvat M., Mohammadi M (2004) Effects of fluorescent pseudomonas on Pythium ultimum casual agent of seed rot of common bean. Iranian J Agric Sci. 34: 793-807

Bardin SD, Huang HC, Moyer JR (2004) Control of Pythium damping-off of sugar beet by seed treatment with crop straw powders and a biocontrol agent. Biological Control. 29: 453-460

Bruehl GW (1983) Nonspecific genetic resistance to soilborne fungi. Phytopathology. 73: 948-951

Cormack MW, Harper FR (1952) Resistance in safflower to root rot and rust in Alberta. Phytopathol. 42: 5 (Abstr)

El-Bramawy M, Abdul Wahid OA (2006) Field resistance of crosses of sesame (Sesamum indicum L.) to charcoal root rot caused by Macrophomina phaseolina (Tassi.) Goid. Plant Protect Sci. 42: 66-72

Falconer FS, MacKay TFC (1996) Introduction to Quantitative Genetics. 4th edn. Longman Group Ltd

Fehr WR (1987) Heritability. In: Fehr WR (ed) Principles of Cultivar Development: Theory and Technique. MacMillan Publishing Company, New York

Ghaderi M, Pahlevani M, Razavi SE (2011) Inheritance of Resistance to 'Pythium ultimum' in Safflower Determined by Generation Means Analysis. Australian Journal of Crop Science. 5:439-446

Govindappa M, Lokesh S, Ravishankar Rai V (2005) A new stem-splitting symptom in safflower caused by Macrophomina phaseolina. Phytopathology. 153: 560-561

Higginbotham RW, Paulitz TC, Campbell KG, Kidwell KK (2004) Evaluation of adapted wheat cultivars for tolerance to Pythium root rot. Plant Dis. 88: 1027-1032

Hollingsworth CR, Gray FA, Groose RW (2005) Evidence for the heritability of resistance to brown root rot of alfalfa, caused by Phoma sclerotioides. Can J Plant Pathol. 27: 64-70

Huang HC, Morrison RJ, Mundel HH, Barr DJS, Klassen GR, Buchko J (1992) Pythium sp. "group G”, a form of Pythium ultimum causing damping-off of safflower. Can J Plant Pathology. 14: 229-232

Johnson LF, Palmer GK (1985) Symptom variability and selection for reduced severity of cotton seedling disease caused by Pythium ultimum. Plant Dis. 69: 298-300

Johnson R (1983) Genetic background of durable resistance. In: Lamberti F, Waller JM, Van der Graaff NA (ed) Durable Resistance in Crops. Plenum Press, New York

Kolte SJ (1985) Diseases of annual edible oilseed crops, Vol. III: Sunflower, safflower, and nigerseed diseases. CRC Press, Boca

Kozik E, Foolad MR, Jones RA (1991) Genetic analysis of resistance to Phytophthora root rot in tomato Lycopersicon esculentum Mill. Plant Breeding. 106: 27-32

Kulkarni RN Baskaran K (2003) Inheritance of resistance to Pythium dieback in the medicinal plant periwinkle. Plant Breeding 122:184-187

Mundel HH, Hung HC, Kozub GC, Daniels CRG (1997) Effect of soil moisture, soil temperature and seedborn Alternaria carthami, on emergence of safflower (Carthamus tinctorius L.). Bot Bull Acad Science. 38: $257-262$ 
Mundel HH, Huang HC, Kozub GC, Barr DJS (1995) Effect of soil moisture and temperature on seedling emergence and incidence of Pythium damping-off in safflower (Carthamus tinctorius L.). Can J plant sci. 75: 505-509

Pahlavani MH, Razavi SE, Mirizadeh I, Vakili S (2007) Field screening of safflower genotypes for resistance to charcoal rot disease. IJPP 1:45-52

Palooj E (2010) Field screening of safflower germplasm for finding genetic resistance sources to Pythium ultimum. MsC Thesis, Gorgan University of Agricultural Sciences and Natural Resources

Rosso ML, Rupe JC, Chen P, Mozzoni LA (2008) Inheritance and Genetic Mapping of Resistance to Pythium Damping-Off Caused by Pythium aphanidermatum in 'Archer' Soybean. Crop Sci 48:2215-2222

Rubis DD (1981) Development of a root rot resistance in safflower by introgressive hybridization and thinhull facilitated recurrent selection. In: Knowles Pf (ed) Pape presented at the First International Safflower Conference, Univ Calif Davis, California, USA, 12-16 July 1981

Sharifnabi B, Saeidi G (2004) Preliminary evaluation of different genotypes of safflower (Carthamus tinctorius L.) to Fusarium root rot disease, JWSS. 8: 219-227

Thomas CA (1970) Effect of temperature on Pythium root rot of safflower. Plant Dis Rep. 54: 300

Yang DE, Jin DM, Wang B, Zhang DS, Nguyen HT, Zhang CL, Chen SJ (2005) Characterization and mapping of Rpil, a gene that confers dominant resistance to stalk rot in maize. Mol Gen Genomics 274:229234

Zhang R X, Gossen BD (2007) Heritability estimates and response to selection for resistance to Mycosphaerella blight in pea. Crop Sci. 47: 2303-2307 